\title{
Transfer of Cubic Boron Nitride Grinding Wheel Wear Products to the Nickel Alloy Surface
}

\author{
Vladimir A. Nosenko ${ }^{1, *}$, Aleksandr V. Fetisov ${ }^{1}$, and Semen P. Kuznesov ${ }^{2}$ \\ ${ }^{1}$ Volzhsky Polytechnic Institute (branch) of Volgograd State Technical University 42a Engels St., \\ Volzhsky, 404121, Russia \\ ${ }^{2}$ Volgograd State Technical University 28 Lenin Avenue, Volgograd, 400005, Russia
}

\begin{abstract}
The article summarizes the results of microscopic and x-ray spectral studies of objects embedded in the surface layer of a nickel alloy after grinding with a wheel of cubic boron nitride $(\mathrm{CBN})$ on a ceramic bond. In the introduction, the authors analyzes the results of research on the use of $\mathrm{CBN}$ as an abrasive material. Unlike silicon carbide wheels, CBN tools are a more complex and multi-component structure, which has a significant impact on the self-sharpening of the abrasive tool and the transfer of material. The purpose of this article is to detect and identify the wear products of a CBN grinding wheel on the treated surface of a nickel alloy. As a result of studying the morphology of the alloy surface after grinding with CBN wheels, foreign objects embedded in the metal were detected with a scanning two-beam electron microscope. The chemical composition of the objects was studied by x-ray spectral microanalysis. Based on the obtained spectrograms, the objects were divided into three groups, including peaks of x-ray characteristic radiation: boron and nitrogen characteristic of $\mathrm{CBN}$ grains; aluminum and oxygen characteristic of corundum; oxygen, silicon, aluminum, and some elements characteristic of a ceramic bond. Tables of the chemical composition of the studied objects are provided. Conclusions. The transfer of CBN grinding whee wear products from to the treated surface is experimentally proved.
\end{abstract}

\section{Introduction}

Nickel alloys have excellent properties for use as structural materials. However, the choice of these alloys instead of, for example, stainless steels, is justified only when there is a need for a product that works in severe conditions, with a low level of maintenance and requires an increased no-failure service life, which is associated with a relatively high cost. Parts of this kind are in demand in the most knowledge-intensive branches of mechanical engineering, such as the nuclear, oil, aircraft and engine industries, where nickel alloys are widely used [1].

Nickel alloys have low thermal conductivity and sufficiently high adhesive activity to tool materials, thus making the grinding of nickel-based alloys a difficult task [2]. Various

\footnotetext{
* Corresponding author: vladim.nosenko2014@yandex.ru
} 
surface defects may occur during the grinding process: micro-cavities, subsurface structural changes, micro-cracks, and the adhesion of abrasive particles to the processed metals [3, 4].

Adhering materials, impregnation and cauterization caused by the intense adhesive activity of nickel, which is the basis for these alloys, largely determines the grindability of alloys [3, 5]. The effect of adhesion processes on the treated surface at different temperatures (up to $1,300^{\circ} \mathrm{C}$ ) was studied in [6]. Images of the surface of the $\mathrm{K} 417$ nickel alloy obtained by grinding in different modes with wheels made of electrocorundum and cubic boron nitride are given. The grinding temperature was used as a controlled parameter. The authors believe that an increase in temperature causes an increase in the intensity of adhesive interaction, although an increase in the plasticity of the material can also affect the mutual transfer of materials.

Scanning electron microscopy was used to study the surfaces of various nickel alloys when grinding with an abrasive tool made of electrocorundum [7]. Foreign crystal objects were found on the alloy surface. Based on their appearance, objects are classified as wear products of abrasive tools. One of the first proofs of the transfer of abrasive material to the treated surface was obtained when grinding a titanium alloy with a silicon carbide tool. Using the method of electron micro x-ray spectral analysis on the processed surface, the increase in a concentration of silicon $[8,9]$ was identified. On this basis, a quantitative criterion for evaluating the intensity of contact interaction by the increase of concentration of abrasive tool chemical elements on the treated surface $[10,11]$. When processing various metals with tools made of electrocorundum and silicon carbide, the fact of material transfer and impregnation of the treated surface with crystalline wear products has been experimentally proved [12-16].

Crystalline objects embedded in the treated surface are stress concentrators that reduce the fatigue strength of the material, especially when working under alternating loads. Therefore, the study of the transfer of abrasive tool crystalline wear products to the treated surface is a priority scientific task.

The transfer of materials is significantly influenced by the adhesive interaction of the abrasive material and the processed metal. Among the factors that have a significant impact on the adhesion interaction are lubricating and cooling process media, grinding and dressing modes [17-19]. The most effective way to reduce the intensity of adhesive interaction is to use inert abrasive materials, in particular, cubic boron nitride (CBN). The use of CBN grinding wheels provides a significant increase in the cutting capacity of the abrasive tool and the quality of the treated surface [20, 21]. However, when grinding the most adhesively active alloys with a CBN abrasive tool, the treated surface may be impregnated with abrasive tool crystalline wear products [22]. When grinding nickel alloys, the transfer of CBN abrasive tool wear products is insufficiently studied.

The objective is to study the transfer of abrasive tool material and impregnation of the treated surface with crystalline wear products when grinding a nickel-based alloy with a tool made of cubic boron nitride on a ceramic bond.

\section{Methodology}

Nickel alloy N1 (nickel content 99.93\%) was used as the processed material. Grinding was performed on a precision profile numerically-controlled Smart-B1224III CHEVALIER grinding machine with a cubic boron nitride wheel 1 A1 $350 \times 16 \times 127 \times 5(\mathrm{CBN} 30$ B126 $100 \% \mathrm{M}$ V characteristics). Processing mode: grinding speed $-35 \mathrm{~m} / \mathrm{s}$, longitudinal table feed speed $-12 \mathrm{~m} / \mathrm{min}$, radial feed $-0.005 \mathrm{~mm} / \mathrm{x}, 0.5 \mathrm{~mm}$ allowance. The size of the surface area to be treated is $50 \times 10 \mathrm{~mm}$. Lukoil Freo was used as a cooling lubricant. Detailed research methods are given in [22]. 
The state of the relief and the chemical composition of the contacting surfaces were studied using a FEI Versa 3D LoVac scanning two-beam electron microscope. Micro-X-ray spectral analysis of objects was performed in a microscope chamber.

\section{Results}

When grinding a nickel alloy, the metal adheres to the grain tops of the abrasive tool working surface, which is confirmed by optical images of the wheel working part (Fig. 1).

The shape of the metal particles can be divided into chips and adhering materials (tips). For example, chip 1 (Fig. 1a) has a curved shape. Length of the chip is $0.4 \mathrm{~mm}$, width is $0.03 \mathrm{~mm}$. In the middle part, the chips are bifurcated, the thickness in this part is about 0.17 $\mathrm{mm}$. One of the largest adhering tips is shown near the center of Fig. 1b. Its maximum length is $1.3 \mathrm{~mm}$, and its width is $0.46 \mathrm{~mm}$. The total area of the adhering tip is about 0.6 $\mathrm{mm}^{2}$. Assuming that on $1 \mathrm{~mm}^{2}$ of the wheel working surface there are 8 grain tops, we obtain about 5 grains covered by the adhesive material.

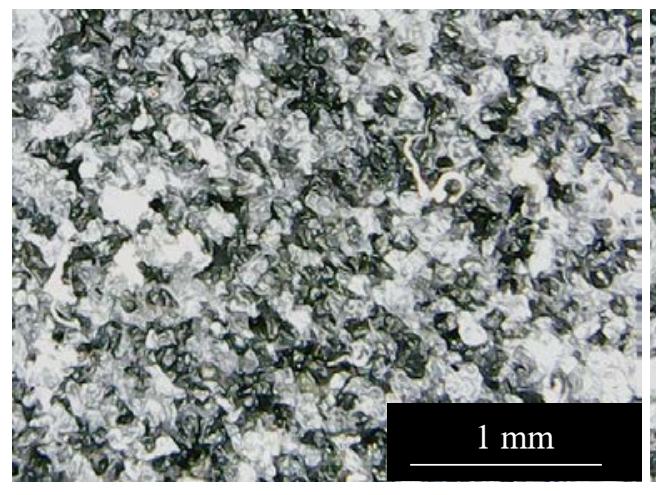

a)

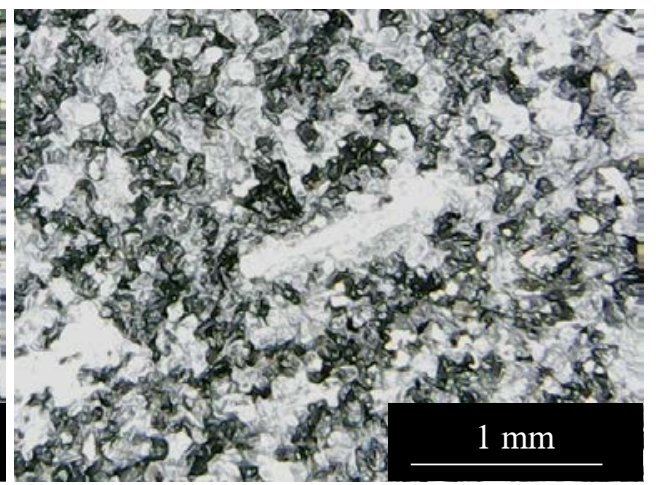

b)

Fig. 1. Grinding wheel working surface

The treated surface of nickel (Fig. 2a) is obtained as a result of interaction with numerous abrasive grains of cubic boron nitride. Scratches on the nickel surface are clearly distinguishable, which indicates a low intensity of the adhesive interaction of nickel with the CBN abrasive tool.

Some scratches are intermittent and located at an angle to the direction of the main movement, which may indicate that part of the grain is chipped or the grain is torn out of the wheel bond and moved as a result of collision with another grain. As a result, the crystal is embedded in the surface layer of the metal. Transfer of the adhered metal from the wheel surface (Fig. 1b) to the treated surface may also be accompanied by chipping of microparticles or part of a grain or its pulling out of the bond [6].

The assumed grinding wheel wear products were found in the reflected (back-scattered) electron images (Fig. 2b). This method is widely used in scanning electron microscopy and provides information about the difference in the effective atomic number of the analyzed material. Information about the atomic number is necessary to detect the $\mathrm{CBN}$ abrasive tool wear products consisting of substances with the atomic number being less than the atomic number of nickel. Wear products can be CBN grains consisting of boron and nitrogen, fillers introduced into the abrasive mixture in the manufacture of tools, i.e. corundum grinding powders (chemical elements $\mathrm{Al}$ and $\mathrm{O}$ ), bond fragments that include $\mathrm{O}, \mathrm{Si}, \mathrm{Al}$. 


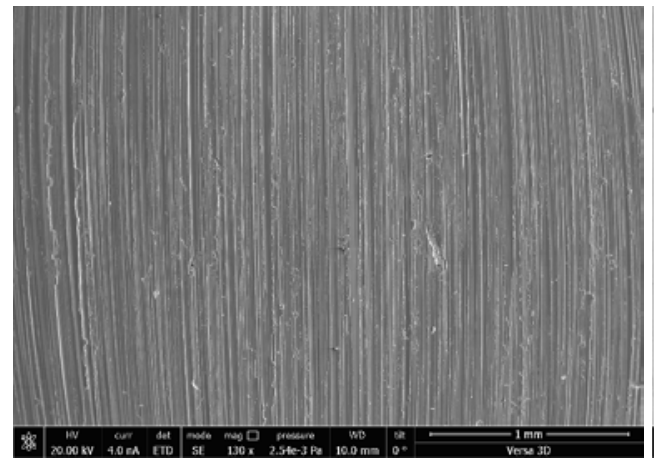

a)

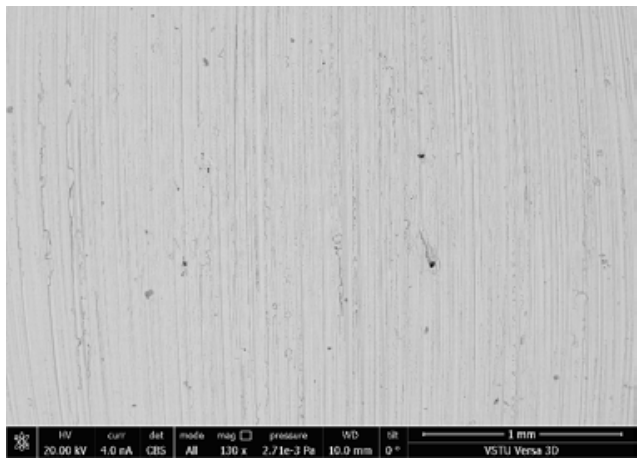

b)

Fig. 2. Morphology of the treated surface in reflected (a) and elastically scattered (b) electrons

The difference in the effective atomic number of the substance on the sample surface is that the images obtained by back-scattered electrons, on a uniform light background representing the nickel surface, contain inclusions of a darker color (Fig. 2b). This may indirectly indicate that the embedded objects are products of grinding wheel wear. It is possible that darker areas of the surface may be formed as a result of the weakening of the characteristic radiation energy in the surface recesses. However, images obtained in backscattered electrons make it easier to detect embedded objects. The objects were identified using pointed $x$-ray spectral analysis.

Foreign inclusions can be located at the bottom of the furrow, the shape of which corresponds to the trajectory of movement of the chipped abrasive grain on the treated surface (Fig. 3a, c). Also, some objects may be fully embedded in the billet. In this case, they may be located in the cavities formed during processing (right part of Fig. 3e) or under a layer of metal that contains traces of abrasive grains (left part of Fig. 3e). This phenomenon is explained by the interaction of chipped abrasive grains with the grinding wheel working surface.

The areas where $\mathrm{x}$-ray spectral analysis was performed are shown in Fig. 3b, d, f, and xray images are shown in Fig. 4. All x-ray images show an energy peak corresponding to nickel, which indicates the transfer of nickel over the surface of the analyzed objects. It is possible that the value of the electron activation energy zone may exceed the material boundary of the analyzed crystal objects and excite the characteristic electron radiation in the main treated surface. The remaining peaks correspond to the sets of elements that are characteristic of the expected grinding wheel wear products: $\mathrm{B}, \mathrm{N}, \mathrm{O}, \mathrm{Na}, \mathrm{Al}, \mathrm{Si}$.

Quantitative analysis of the chemical element content, which, with a $10 \%$ error, allows us to identify this object as boron nitride. It is also worth noting that deviations from the 1:1 ratio may be caused by imperfection of the evaluation method. It is known that due to the roughness of the surface, this method has a significant error in determining light-weight elements.

According to the results of the x-ray analysis shown in Fig. $4 \mathrm{~b}$, the content of $40 \%$ aluminum and $60 \%$ oxygen was determined, which corresponds to the ratio of $2: 3$ that is typical for $\mathrm{Al}_{2} \mathrm{O}_{3}$ corundum crystals. The presence of these particles on the surface is associated with the use of a filler in the manufacture of wheels of $\mathrm{CBN}$, which is used as corundum. 


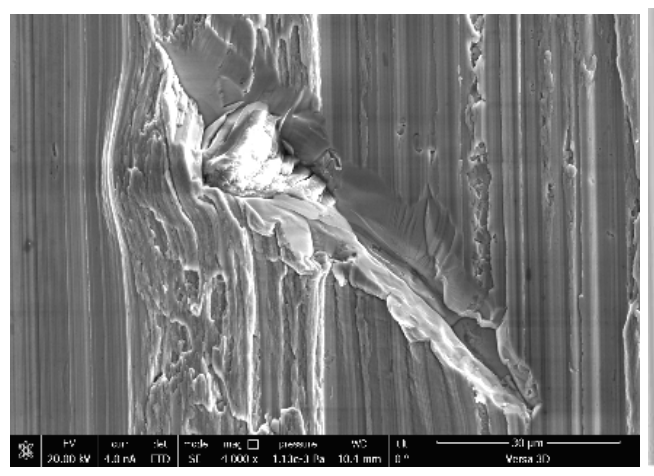

a)

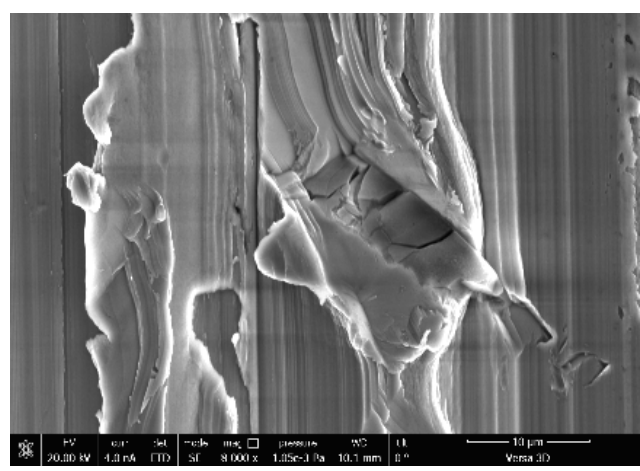

c)

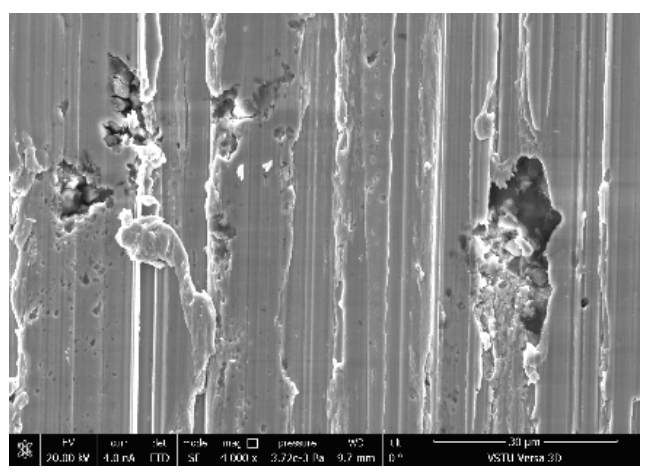

e)

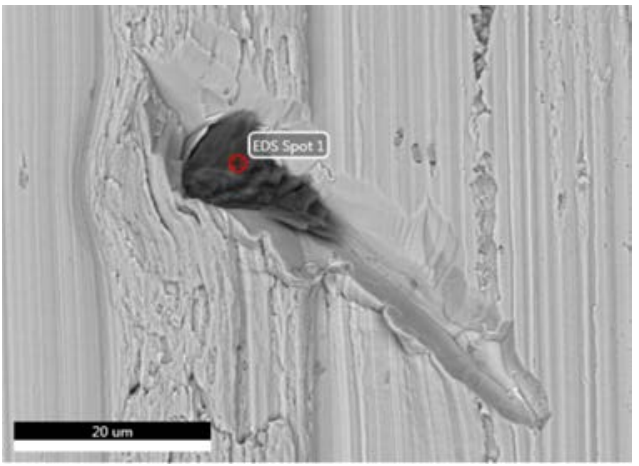

b)

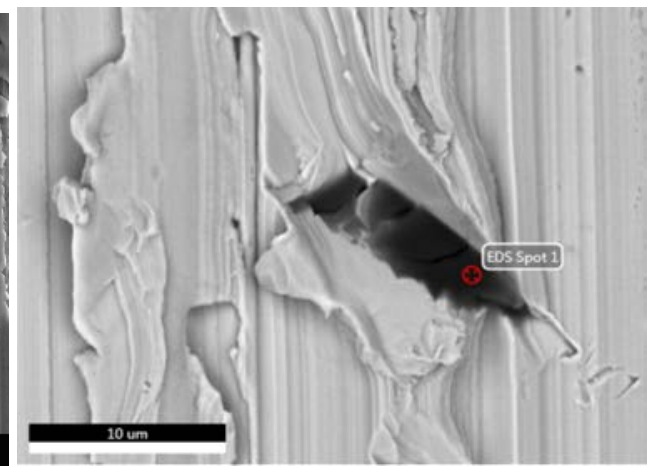

d)

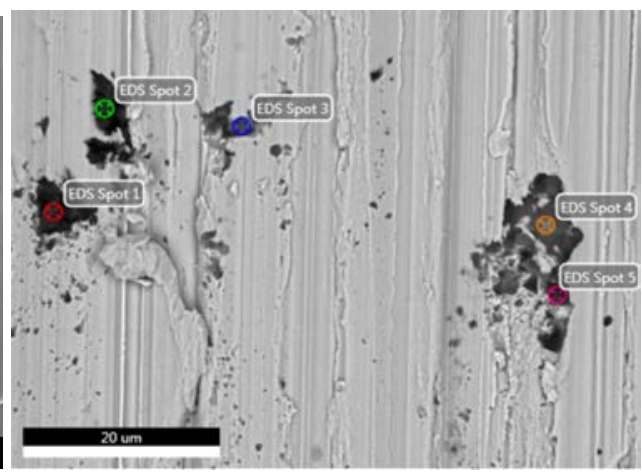

f)

Fig. 3. Electronic images of foreign inclusions in secondary (a, c, e) and back-scattered electrons (b, $\mathrm{d}, \mathrm{f})$

In contrast to the abrasive material and filler, the exact composition of the ceramic bond is a trade secret of the manufacturer. It is known that its main component is alumina-silica glass with the addition of oxides of alkaline and alkaline-earth metals [21]. Based on this, the bond fragments must have a high oxygen content, the presence of silicon and aluminum, and possible presence of $\mathrm{Li}, \mathrm{Na}, \mathrm{K}, \mathrm{Mg}, \mathrm{Ca}$, and $\mathrm{B}$. The X-ray image (Fig. 4c) shows peaks of oxygen, silicon, aluminum, and sodium. The ratio of these elements, taking into account the error, corresponds to $\mathrm{SiO}_{2}, \mathrm{Al}_{2} \mathrm{O}_{3}, \mathrm{Na}_{2} \mathrm{O}$. Based on this, we concluded that the embedded fragment of the grinding wheel bond is located at point 4 (Fig. 3f). 


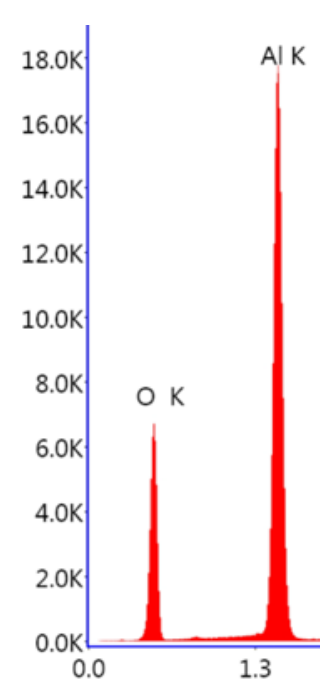

a)

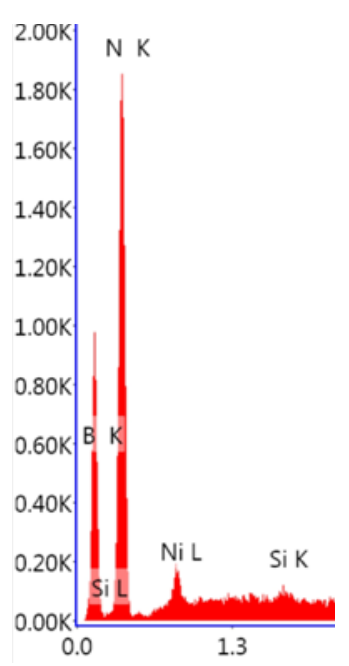

b)

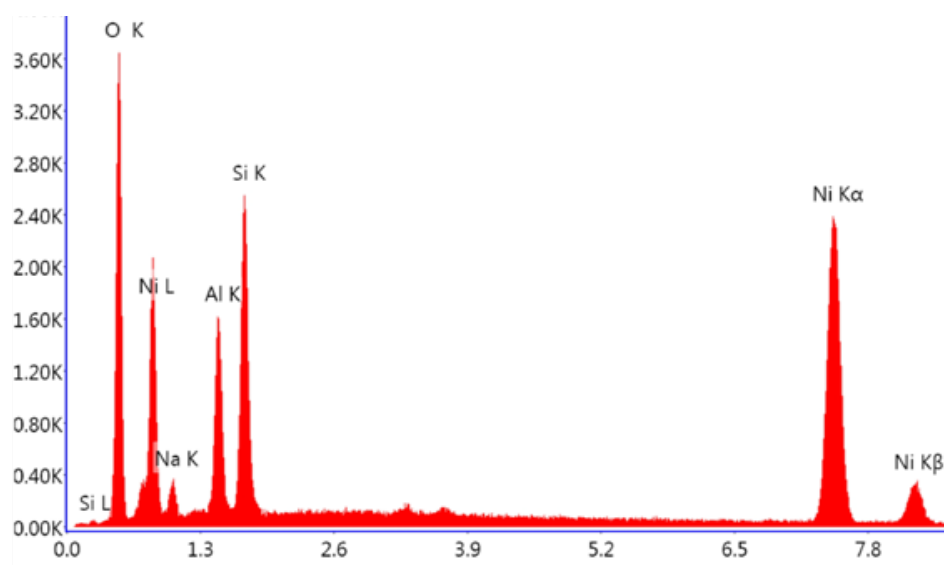

c)

Fig. 4. X-ray images of embedded objects: (a) - Spot 1, Fig. 3a, (b) - Spot 1, Fig. 3d, (c) - Spot 4, Fig. $3 f$.

Table 1. Content of chemical elements.

\begin{tabular}{|l|c|c|c|c|c|c|c|c|c|c|c|}
\hline $\begin{array}{l}\text { Statistical } \\
\text { parameters }\end{array}$ & \multicolumn{2}{|c|}{ Fig. 4a } & \multicolumn{4}{|c|}{ Fig. 4b } & \multicolumn{5}{c|}{ Fig. 4c } \\
\hline Element & O & B & B & N & Si & Ni & O & Na & Al & Si & Ni \\
\hline Atomic $\%$ & 60 & 45 & 45 & 53 & 0.05 & 0.6 & 45 & 6 & 9 & 11 & 29 \\
\hline Error \% & 7 & 10 & 10 & 9 & 31 & 9 & 8 & 12 & 8 & 7 & 2 \\
\hline
\end{tabular}

\section{Conclusions}

During processing, the billet material is transferred to the tool surface and the grinding wheel wear products are transferred to the treated surface.

The method of obtaining images in the backscattered electron mode significantly facilitates the detection of grinding wheel wear products on the treated surface. 
The wear products of the grinding wheel embedded in the treated surface are crystals of cubic boron nitride, corundum, which is used as a filler in the manufacture of abrasive tools, as well as particles of ceramic bond.

The reported study was funded by RFBR, project number 19-38-90322\19

\section{References}

1. Weber J.H. Nickel and Nickel Alloys: An Overview / J.H. Weber, M.K. Banerjee // Reference Module in Materials Science and Materials Engineering. 2016. DOI: 10.1016/B978-0-12-803581-8.02572-8

2. Miao Q. Comparison on grindability and surface integrity in creep feed grinding of GH4169, K403, DZ408 and DD6 nickel-based superalloys / Q. Miao W. Ding, W. Kuang, C. Yang, // Journal of Manufacturing Processes. 2019. Vol. 49. P. 175-186. DOI: 10.1016/j.jmapro.2019.11.027.

3. Liao Z. State-of-the-art of surface integrity in machining of metal matrix composites / Z. Liao, A. Abdelhafeez, H. Li, Y. Yang, O. Gavalda Diaz, D. Axinte // International Journal of Machine Tools and Manufacture. 2019. Vol. 143. P. 63-91. DOI: 10.1016/j.ijmachtools.2019.05.006

4. Lv X. (2020). Deep Active Learning for Surface Defect Detection / X. Lv, F. Duan, J. Jiang, X. Fu, L. Gan, // Sensors. 2020. Vol. 20. 1650. DOI: 10.3390/s20061650.

5. Thiagarajan C. Experimental evaluation of grinding forces and surface finish in cylindrical grinding of $\mathrm{Al} / \mathrm{SiC}$ metal matrix composites / C. Thiagarajan, R. Sivaramakrishnan, S. Somasundaram //. Proc. IMechE Part B: J. Engineering Manufacture. 2011. Vol. 225. P. 1606-1614. DOI: 10.1177/0954405411398761

6. Xu X. Mechanisms of abrasive wear in the grinding of titanium (TC4) and nickel (K417) alloys / X. Xu, Y. Yu, H. Huang // Wear, 2003. Vol. 255, P. 1421-1426

7. Miao Q. Comparative investigation on wear behavior of brown alumina and microcrystalline alumina abrasive wheels during creep feed grinding of different nickelbased superalloys / Q. Miao, W. Ding, Y. Gu, J. Xu // Wear, 2019. Vol. 426-427. P. 1624-1634. DOI: 10.1016/j.wear.2019.01.080

8. Sayutin G.I. Issledovanie mikrohimicheskih izmenenij poverhnosti titanovyh splavov pri shlifovanii [Investigation of microchemical changes in the surface of titanium alloys during grinding] / G.I. Sayutin, V.A. Nosenko // Treniye I iznos. 1983. -. Vol. 2 no.4. pp. 348-352. (In Russian).

9. Sayutin G.I. Perenos kremniya na poverhnost' metalla pri shlifovanii krugami i mikrocarapanii indentorami iz karbida kremniya [Transfer of silicon to the metal surface during grinding circles and micro-scratching with silicon carbide indenters] / G.I. Sayutin, V.A. Nosenko, N.F. Larionov // Treniye I iznos. 1984. Vol 3. pp. 513-519. (In Russian).

10. Nosenko V.A. Kriterij intensivnosti vzaimodejstviya obrabatyvaemogo i abrazivnogo materialov pri shlifovanii [Criterion for the intensity of interaction between the processed and abrasive materials during grinding]// Problemy Mashinostroeniya I Nadezhnosty mashin. 2001. Vol 5. pp. 85-91. (In Russian).

11. Nosenko V.A. K voprosu ob intensivnosty contaktnogo vzaimodeystviya d-perehodnyh metllov s carbidom cremniya pri shlifovanii [On the intensity of contact interaction of d-transition metals with silicon carbide during grinding] // Problemy Mashinostroeniya I Nadezhnosty mashin. 2002. Vol 5. pp. 78-84. (In Russian).

12. Wang R.X., Effects of abrasive material and hardness of grinding wheel on rail grinding behaviors / R.X. Wang, K. Zhou, J.Y. Yang, H.H. Ding, W.J. Wang, J. Guo, Q.Y. Liu // Wear. 2020. Vol. 454-455. 203332. DOI: 10.1016/j.wear.2020.203332 
13. Mello A. V., Surface Grinding of Ti-6Al-4V Alloy with SiC Abrasive Wheel at Various Cutting Conditions / A. V. de Mello, R. B. de Silva, Á. R. Machado, R. V. Gelamo, R. F. M. de Oliveira // Procedia Manufacturing. Vol. 10. 2017. P. 590-600. DOI: 10.1016/j.promfg.2017.07.057

14. Nosenko, V.A., Fetisov, A.V., Puzyrkova, V.Y. (2018) Morphology and chemical composition of silicon carbide surfaces interacting with iron, cobalt, and nickel in microscratching. / V.A. Nosenko, A.V. Fetisov, V.Y. Puzyrkova, // Solid State Phenomena. Vol. 284. 2018. P. 363-368. DOI: 10.4028/www.scientific.net/SSP.284.363

15. Nosenko, S.V., Nosenko, V.A., Kremenetskii, L.L. (2017) The Condition of Machined Surface of Titanium Alloy in Dry Grinding. Procedia Engineering. 206. PP. 115-120.. DOI: 10.1016 / j.proeng.2017.10.446.

16. Nosenko V.A. Issledovanie himicheskogo sostava poverhnostnogo sloya titanovogo splava pri shlifovanii ego krugom iz karbida kremniya bez ispol'zovaniya sots [Investigation of the chemical composition of the surface layer of a titanium alloy when grinding it with a circle of silicon carbide without the use of coolant]/ Nosenko S.V., Nosenko V.A., Krutikova A.A., Kremenetskyi L.L.// STIN. - 2015. - № 1. - C. 26-29.

17. Nosenko V.A. Sovershenstvovanie abrazivnogo instrumenta na bakelitovoj svyazke [Improvement of the abrasive tool on a bakelite bundle] // Problemy Mashinostroeniya I Nadezhnosty mashin. 2004. Vol 3. pp. 85-90. (In Russian).

18. Nosenko S.V. INFLUENCE OF ABRASIVE TOOL DRESSING ON STATE OF RELIEF OF MACHINED SURFACE OF TITANIUM ALLOY AT COUNTER DEEP GRINDING / Nosenko S.V., Nosenko V.A., Kremenetskyi L.L. // Vestnik Mashinostroeniya. 2014. Vol 7. pp. 64-68. (In Russian).

19. Nosenko S.V. The effect of the operating speed and wheel characteristics on the surface quality at creep-feed grinding titanium alloys / S.V. Nosenko, V.A. Nosenko, A.A. Koryazhkin, // Solid State Phenomena. 2018. Vol. 284. P. 369-374. DOI: 10.4028/www. scientific.net/SSP.284.369 (In Russian).

20. Soler Y. I. THE RESEARCH OF SPARKING-OUT EFFECT ON THE ROUGHNESS AT THE PLATE FLAT FOR THE FLAT CBN-GRINDING OF THE STEEL BRAND P9M4K8 Soler Y. I., Prokopeva A.V. Obrabotka metallov (tekhnologiya, oborudovanie, instrumenty) $=$ Metal Working and Material Science, 2009, Vol. 1, no. 42, pp. 24-27. (In Russian).

21. Starkov V.K. STRUCTURAL MODELING STRUCTURES OF GRINDING CIRCLES FROM CUBIC NITRIDE OF A PINE FOREST / Starkov V.K., Riabcev S.A., Petrosian L.S. // Vestnyk MGTU "Stankin", 2009, Vol. 1 (5). pp. 87-97 (In Russian).

22. Nosenko V.A., Fetisov A.V., Kuznetsov S.P. Morphology and chemical composition of the titanium alloy surface at the initial stage of grinding with a cubic boron nitride wheel. Obrabotka metallov (tekhnologiya, oborudovanie, instrumenty) = Metal Working and Material Science, 2020, vol. 22, no. 2, pp. 30-40. DOI: 10.17212/19946309-2020-22.2-30-40. (In Russian). 